\title{
PATTERN OF REGIONAL OFFICE / CITY OFFICE SPACE POLA PENATAAN RUANG KANTOR KABUPATEN / KOTA
}

\author{
Hidayatul Mustafit ${ }^{1)}$, Gatoet Wardianto ${ }^{2)}$, Adi Sasmito ${ }^{3)}$ \\ Program Studi Arsitektur, Fakultas Teknik, Universitas Pandanaran \\ h.mustafit1998@gmail.com ${ }^{1)}$ \\ gatoetwardianto@yahoo.com ${ }^{2)}$ \\ sasmitoadi308@gmail.com ${ }^{3}$
}

\begin{abstract}
Abstrak
Indonesia adalah negara yang memiliki wilayah yang terdiri dari beberapa daerah provinsi. Daerah provinsi itu terdiri dari daerah kabupaten dan daerah kota. Setiap daerah itu terdapat sistem pemerintah yang mengatur dan diatur oleh undang-undang dasar 1945. Pemerintah daerah yang dimaksut adalah Gubernur, Bupati, atau Walikota dan perangkat daerah sebagai unsur penyelenggara pemerintah daerah. Pemerintah daerah mengatur dan mengurus sendiri urusan pemerintahan menurut asas otonomi dan tugas pembantuan. Pemerintah Kabupaten merupakan unsur utama dalam mengatur Pemerintah di suatu daerah. Dalam melaksanakan otonomi daerahnya, Pemerintah Kabupaten/kota membutuhkan sarana dan prasarana untuk mewadahi aparatur sebagai tempat kerja bagi pegawai yaitu kantor pemerintahan.

Kantor Pemerintah Kabupaten berfungsi sebagai wadah/tempat dari aktivitas/kegiatan pemerintahan daerah setempat dalam melaksanakan tugas pelayanan kepada masyarakat umum di daerah Kabupaten. Untuk meningkatkan pelayanan masyarakat diperlukan sarana dan prasarana yang memadai salah satunya adalah kantor pemerintah tempat pekerja seorang pegaiwai negeri sipil yang representatif. Sebagai kantor pemerintahan, gedung perkantoran harus memiliki karakteristik bentuk yang spesifik dan juga harus mempunyai sistem penataan bangunan yang baik dan terencana secara Arsitektural. Bangunan ini ditujukan untuk mewadahi berbagai kegiatan yang berkaitan dengan pelayanan kepada masyarakat. Gedung kantor yang memadai bertujuan agar menciptakan sistem atau mekanisme kinerja instansi pemerintah yang lebih terintegrasi dan menyeluruh, mewujudkan pola layanan kepada masyarakat yang lebih efektif dan efisien, kantor pemerintah harus mampu mencerminkan suatu lambang kedudukan pusat pemerintahan.
\end{abstract}

Kata kunci: Kantor Pemerintah Kabupaten/Kota, Pola, Ruang Luar

\begin{abstract}
Indonesia is a country that has an area consisting of several provinces. The provincial area consists of districts and city areas. Each of these regions has a government system that regulates and is governed by the 1945 constitution. The regional governments that are adopted are the Governor, the Regent, or the Mayor and the regional apparatus as elements of the regional government. The regional government regulates and manages its own government affairs according to the principle of autonomy and assistance tasks. The Regency Government is the main element in regulating the Government in an area. In implementing regional autonomy, the regency / city government needs facilities and infrastructure to accommodate the apparatus as a workplace for employees, namely government offices.

The Regency Government Office functions as a container / place for the activities / activities of the local government in carrying out its service duties to the general public in the Regency area. To improve community services, adequate facilities and infrastructure are needed, one of which is a government office where workers are representative civil servants. As a government office, office buildings must have specific shape characteristics and must also have a well structured and structured building structuring system. This building is intended to accommodate various activities related to service to the community. An adequate office
\end{abstract}


building aims to create a system or mechanism of performance of government agencies that is more integrated and comprehensive, realizing a more effective and efficient pattern of service to the community, government offices must be able to reflect a symbol of the position of the central government.

\section{Keywords: Regency / City Government Office, Pattern, Outdoor Space}

\section{PENDAHULUAN}

Kantor Pemerintah Kabupaten itu sebagai wadah/tempat dari aktivitas/kegiatan pemerintahan daerah dalam melaksanakan tugas pelayanan kepada masyarakat dan melayani kepentingan umum di wilayah Kabupaten. Sebagai kantor pemerintahan, gedung perkantoran harus memiliki karakteristik bentuk yang spesifik dan juga harus mempunyai sistem penataan bangunan yang baik dan terencana secara Arsitektural. Gedung Kantor Pemerintah diantaranya adalah kantor Bupati beserta jajaranya yang berkaitan dengan proses pelayanan kepada masyarakat.

\section{Skema Penelitian}

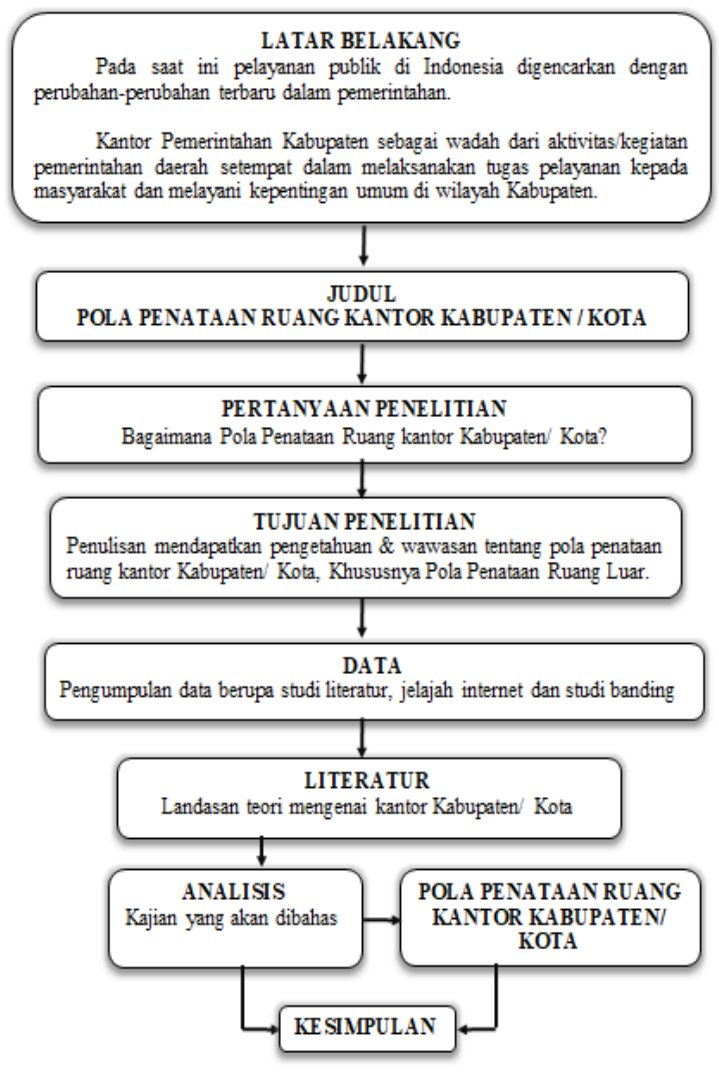

Oleh karena itu pengetahuan tentang pola penataan ruang luar bangunan Kantor
Pemerintah Kabupaten/Kota perlu direncanakan dengan baik agar tepat sasaran. Kemudian metode kualitatif yang digunakan penelitian berupa studi literature buku, jelajah internet dan studi banding. Perencanaan Kantor Pemerintah Kabupaten/Kota yang baik dapat memberikan hasil penataan tata ruang Kabupaten/Kota yang terencana dengan baik sehingga perkotaan menjadi lebih maju.

\section{TINJAUAN TEORI}

\subsection{Organisasi Ruang}

Menjelaskan tentang ruang-ruang yang saling terhubung dan membentuk menjadi sebuah bangunan. Ruang itu sendiri dapat diartikan sesuatu benda yang memiliki Panjang, lebar dan tinggi yang membentuk 3 dimensi.

\subsection{Hubungan-hubungan spasial}

Ruang Dalam Ruang
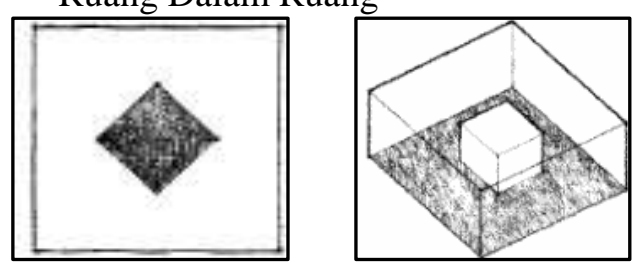

Gambar 1. Ruang Dalam Ruang

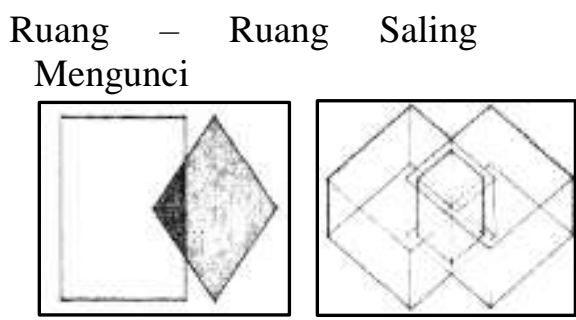

Gambar 2. Ruang saling mengunci

Ruang Saling Berdekatan

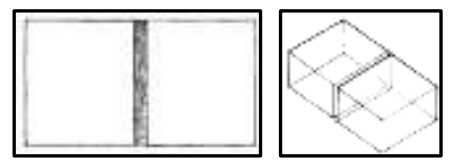

Gambar 3. Ruang yang bersebelahan 
Ruang Yang Dihubungkan Ruang Bersama

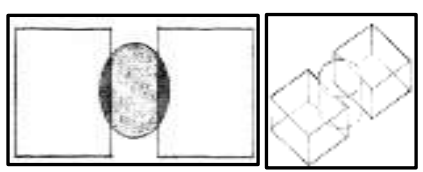

Gambar 4. Ruang-ruang yang dihubungkan oleh ruang bersama

\subsection{Organisasi-Organisasi spasial}

Organisai-Organisai Terpusat

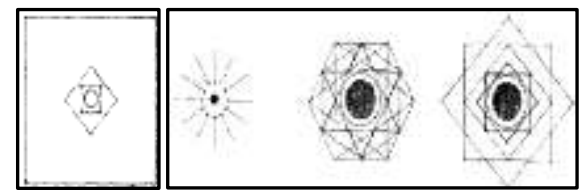

Gambar 5. Organisasiorganisasi terpusat

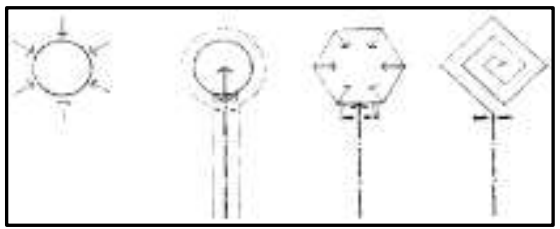

Gambar 6. Bentuk organisasi terpusat

Organisai-Organisai Linier

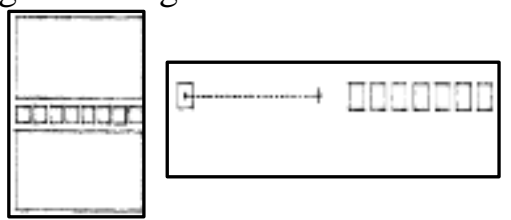

Gambar 7. Organisasi linier

Organisasi linier mempunyai ciri dari pengulangan ukuran, bentuk, dan fungsinya serupa.

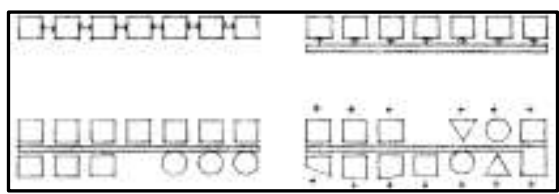

Gambar 8. Macam bentuk organisasi linier

Bentuk organisasi linier yang berbentuk lengkungan akan menutupi sebuah eksterior pada sisi cekungannya serta orientasinya mengarah ke pusat area. Di sisi cekunganya, bentuk ini seolah menghadap ruang dan mengeluarkannya dari arah mereka.

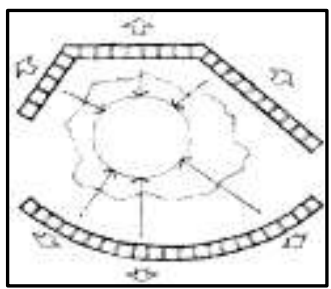

Gambar 9. Bentuk Organisasi Linier

Organisasi-Organisasi Radial

Sebuah ruang terpusat yang menjadi titik sentral organisasi - organisasi linier ruang yang memanjang dengan cara melingkar.

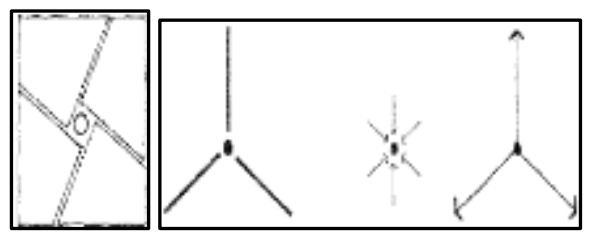

Gambar 10. Organisasi Organisasi Radial

Garis yang membagi fungsi ruang yang berbeda satu sama lain bertujuan untuk merespon kebutuhan kebutuhan individual fungsi ruang dan lingkungan.

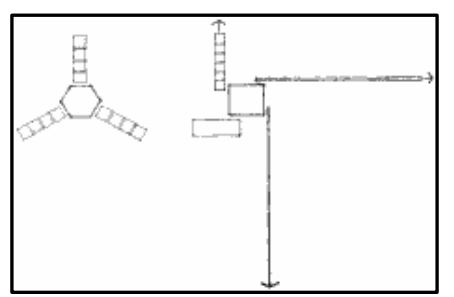

Gambar 11. Bentuk Organisasi Radial

Organisai-Organisai Berklaster

Ruang yang dikelompokan sesuai dengan pembagian.

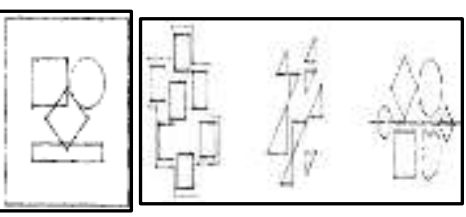

Gambar 12. Organisasi - Organisasi Berklaster

Ruang - ruang terklaster dapat diatur mengelilingi sebuah titik akses 
masuk ke dalam sebuah bangunan ataupun di sepanjang jalur pergerakan yang melaluinya.

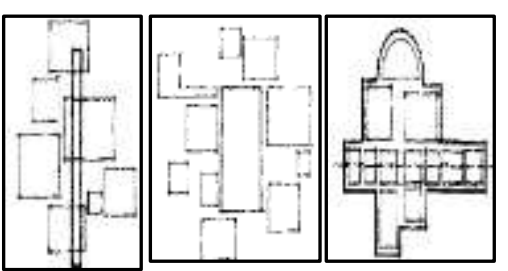

Gambar 13. Jenis Organisasi Berklaster

Organisasi - Organisasi Grid

Ruang - ruang yang diorganisir di dalam area sebuah grid struktur atau rangka kerja tiga dimensi lainnya.
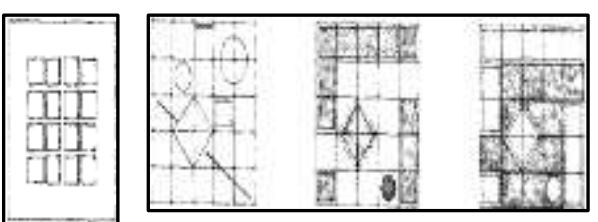

Gambar 14. Organisasi Organisasi Grid

Sebuah grid juga dapat melakukan transformasi laindengan cara menggeser grid untuk mendapatkan alternatif visual dan spasial yang melintasi areanya.

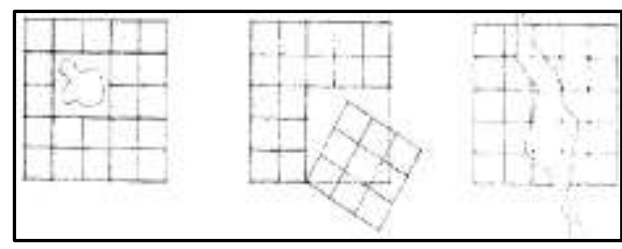

Gambar 15. Jenis Organisasi Grid

\subsection{Persyaratan dan Fasilitas} Pendukung Kantor Pemerintah Kabupaten/Kota

Ruang Workshop

Fasilitas Pendukung Kantor Pemerintah Kabupaten/Kota Ruang Workshop. Berikut merupakan standart dimensi dan layout ruang workshop.

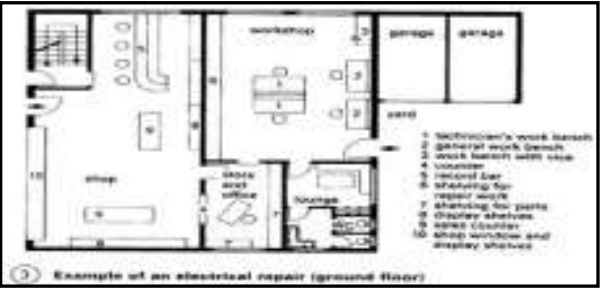

Gambar 16. Dimensi dan penataan ruang workshop

\section{Restoran}

Fasilitas Pendukung Kantor Pemerintah Kabupaten/Kota Ruang Restoran. Berikut merupakan standart dimensi dan layout ruang restoran.

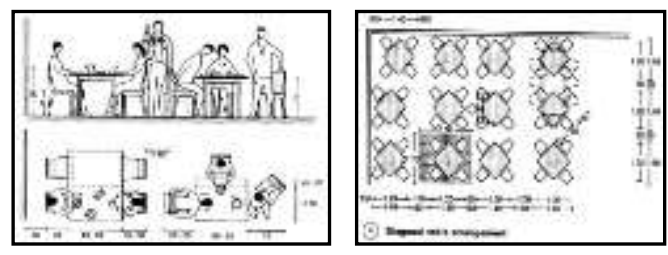

Gambar 17. Dimensi dan penataan ruang restoran

\section{Ruang Office}

Fasilitas Pendukung Kantor Pemerintah Kabupaten/Kota Ruang Office. Berikut merupakan standart dimensi dan layout ruang office.

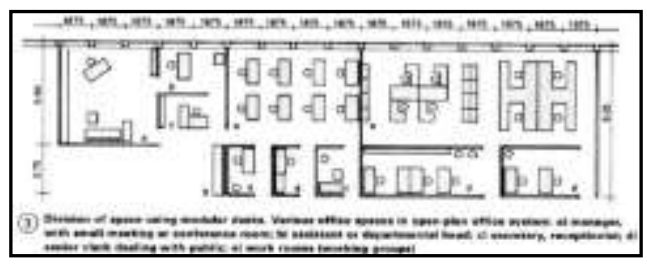

Gambar 18. Dimensi dan penataan ruang office

Potongan Melintang Ruang Office

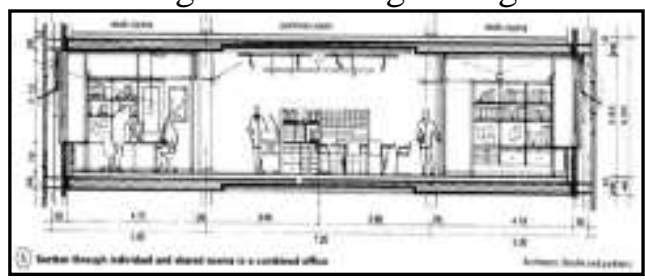

Gambar 19. Dimensi dan penataan ruang office

\section{Ruang Administrasi}

Fasilitas lembaga pembiayaan/adm inistrasi digunakan untuk pengelolaan operasional gedung. 


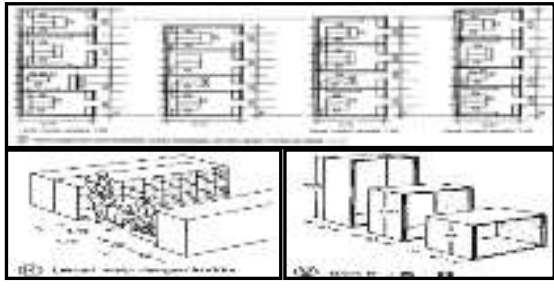

Gambar 20. Dimensi dan penataan ruang Administrasi

Ruang Percobaan, Ruang Pameran, Dokumentasi, Ruang Pakar

Fasilitas Lembaga pembiayaan / administrasi digunakan untuk pengelolaan operasional gedung.

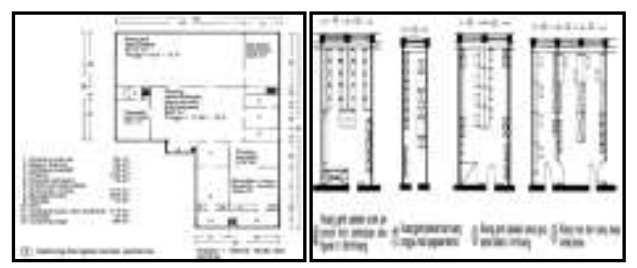

Gambar 21. Dimensi dan penataan ruang Administrasi

\section{Ruang Ibadah}

Fasilitas masjid digunakan untuk berdoa, pusat kebudayaan, tempat pertemuan, pengadilan, sekolahdan universitas.
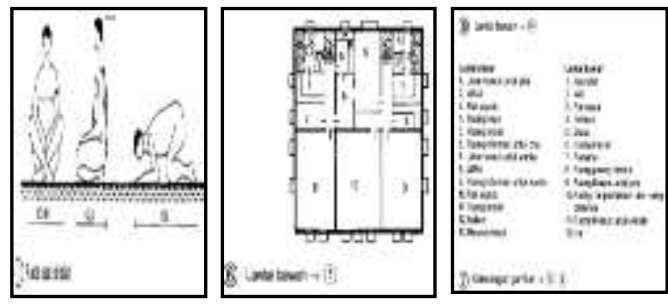

Gambar 22. Dimensi dan penataan ruang Masjid

\section{METODOLOGI PENELITIAN}

\subsection{Pendekatan Penelitian}

Metode kualitatif adalah sebuah metode penelitian yang bersifat mencari penjelasan dengan menggunakan teknik analisis data dilapangan. Pada pelaksanaannya, metode ini menunjukan subjektif dalam proses penelitian dan berfocus pada landasan teori.

Metode Penelitian kualitatif adalah penelitian yang digunakan untuk meneliti pada kondisi objek alamiah, dimana peneliti merupakan instrumen kunci (Sugiyono, 2005).

\subsection{Studi Pustaka}

Studi pustaka merupakan metode pengumpulan data melalui dokumen tertulis, foto, gambar maupun media elektronik yang mendukung proses penelitian. Hasil penelitian juga akan semakin kredibel apabila didukung dokumentasi atau karya tulis akademik dan seni yang telah ada.

\subsection{Studi Kasus}

Objek dalam penelitian ini adalah factor - factor yang memengaruhi pola Penataan ruang luar Kantor Pemerintah Kabupaten/Kota, untuk studi penelitian ada 3 lokasi yaitu :

1. Kantor Pemerintah Kabupaten Bandung

2. Kantor Pemerintah Kabupaten Bekasi

3. Kantor Pemerintah Kabupaten Grobogan

\subsection{Teknik Pengumpulan Data}

Teknik pengumpulan data kualitatif berbagai macam yaitu:

\section{Data Sekunder}

Data sekunder adalah data yang tidak dikumpulkan / diteliti sendiri oleh peneliti, data tersebut didapatkan dari pengumpulan bahan - bahan Perpustakaan atau data yang bersumber secara tidak langsung (Marzuki 2000:56). Data sekunder dalam perancangan Kantor Pemerintah Kabupaten/kota ini diperoleh dari berbagai refrensi, seperti buku, artikel artikel, internet, dan sumber lainnya.

\section{Observasi}

Obeservasi adalah pengamatan yang dilakukan oleh peneliti dapat dilakukan dengan cara melihat dan mensurvey bangunan yang berfokus pada penelitian untuk memperoleh data. Observasi sebagai teknik pengumpulan data kualitatif yang diambil untuk pola penataan ruang luar Kantor Pemerintah Kabupaten/kota adalah:

Studi Literatur Jurnal 
Studi literatur dilakukan untuk mendapatkan sebuah data penelitian, baik dari aspek arsitektur, non-arsitektur, dan tema. Studi literatur juga dapat bersumber dari bacaan dan berbagai macam sumber lainnya.

\section{Studi Kerangka Teoritis}

Studi literatur dilakukan untuk menjelaskan penelitian tentang penataan pola ruang luar Kantor Pemerintah Kabupaten/kota yang sudah ada dengan mempertimbangkan teori dasar tentang hipotesisnya.

\section{Studi Dokumentasi}

Dokumentasi berfungsi sebagai pendukung proses observasi dan wawancara, meliputi pengambilan data-data dari internet/jurnal penelitian yang ada. Dengan keterbatasan waktu dan jarak penulis hanya dapat mengambil data dari jurnal / penelitian yang sudah ada. Dengan ini penulis mengolah data ulang tentang Kantor Pemerintah Kabupaten/kota, guna melengkapi data yang kurang tentang penelitian Kantor Pemerintah Kabupaten/kota.

\subsection{Teknik Analisis Data}

Teknik analisis data yang digunakan dalam penelitian yaitu penelitian kualitatif dengan cara mengumpulkan hasil wawancara, reduksi data, analisis, interprestasi data. Berikut teknik analisis penelitian data:

\section{Reduksi Data}

Reduksi data merupakan penelitian dengan cara mengambil kesimpulan dengan menarik dan diverivikasi hasil data penelitian tersebut.

\section{Menarik Kesimpulan}

Menarik kesimpulan merupakan pengumpulan data dengan menganalisis kualitatif dengan mencari kebutuhan bahan penelitian, mencatat semua hasil penelitian, pola, penjelasan, konfigurasi yang memungkinkan alur sebab dan akibat serta proporsi. Kesimpulan yang semula belum jelas akan dapat terlihat menjadi lebih jelas dan terperinci.

\section{HASIL PEMBAHASAN}

Hasil penelitian dan pembahasan dalam seminar ini berupa obyek yang dijadikan studi kasus sebagai penunjang penelitian Kantor Pemerintah Kabupaten yaitu: Kantor Pemerintah Kabupaten Bandung, Kantor Pemerintah Kabupaten Bekasi, Kantor Pemerintah Kabupaten Grobogan. Pada pembahasan studi kasus, obyek studi kasus yang akan diteliti adalah pola penataan ruang luar dawasan kawasan Kantor Pemerintah Kabupaten/Kota. Perbandingan dalam hal ini lebih ditunjukan pada hanya untuk memperoleh gambaran mengenai pola penataan ruang luar Kabupaten/Kota dengan lokasi yang terpilih, dari penelitian tersebut akan ditarik kesimpulan tentang pola penataan ruang luar Kantor Kabupaten/Kota.

\subsection{Data Bangunan Studi Kasus Kantor Pemerintahan Kabupaten Bandung}
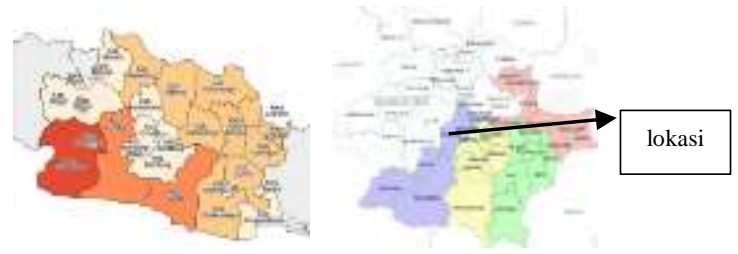

Gambar 23. Peta Lokasi Kantor Pemerintah Kabupeten Bandung

\section{Kantor Pemerintah Kabupaten} Bandung berlokasi di Jl. Perkantoran Pemerintah Kab. Bandung, Pamekaran, Kecamatan. Soreang, Bandung, Jawa Barat. Penataan gedung yang rapi sangat dibutuhkan agar seluruh jajaran pemerintah dapat berkoordinasi dengan baik satu sama lain, agar tidak terjadi mis komunikasi terhadap keputusan-keputusan yang telah dibuat dan di sepakati. Gedung yang berdekatan ini memudahkan Bupati untuk mengkontrol kinerja para bawahan 
yang ada di wilayah pusat Pemerintahan Kabupaten Bandung.

Visi dan Misi Kantor Pemerintah Kabupaten Bandung

Visi

"Memantapkan Kabupaten Bandung yang Maju, Mandiri dan Berdaya Saing, melalui Tata Kelola Pemerintahan yang Baik dan Sinergi Pembangunan Perdesaan, Berlandaskan Religius, Kultural dan Berwawasan Lingkungan"

Misi

1. Peningkatan Kualitas Sumber Daya Manusia.

2. Menciptakan Perekonomi yang dapat Berdaya saing.

3. Mewujudkan Pembangunan Infrastruktur Dasar Terpadu Tata Ruang wilayah.

4. Meningkatkan Kualitas Lingkungan Hidup.

5. Mewujudkan Tata Kelola Pemerintahan yang Baik dan Bersih.

Layanan Kantor Pemerintah Kabupaten Bandung

Fasilitas yang dapat tersedia diantaranya:

a. Kantor Bupati

b. Dinas Kesehatan

c. Dinas Peternakan \& Perikanan

d. Dinas Perindustrian dan perdagangan

e. Dinas Perumahan, Tata Ruang dan Kebersihan

f. BPBD

g. Badan Pertahanan Nasional

h. Masjid

i. Dinas Pendidikan dan Kebudayaan

j. Dinas Sosial

k. Badan Perencanaan Pembangunan Daerah

1. Dinas Ketenagakerjaan

m. Inspektorat

n. Dinas Sumber Daya Air, Pertambangan dan Energi

o. Dinas Lingkungan Hidup

p. Dinas Pemberdayaan Masyarakat dan desa

q. Bank BJB

r. Dinas Kependudukan dan Pencatatan Sipil

s. Dinas Penanaman Modal dan Pelayanan Terpadu Satu Pintu
Pembagian Zoning Kantor Pemerintah

Kabupaten Bandung

Pembagian Zoning di Kantor Pemerintah

Kabupaten Bandung dibagi menurut kebutuhan layanan yang di sediakan oleh pemerintah setempat

\section{Fasilitas Kantor Pemerintah Kabupaten Bandung}

Fasilitas pendukung di dalam kawasan Kantor Pemerintah Kabupaten Bandung Yaitu Lapangan Upacara, Joging track, Taman Perpustakaan dan lain sebagainya.

\section{Organisasi Ruang Kantor Pemerintah Kabupaten Bandung}

Berikut merupakan gambaran dari organisasi ruang:

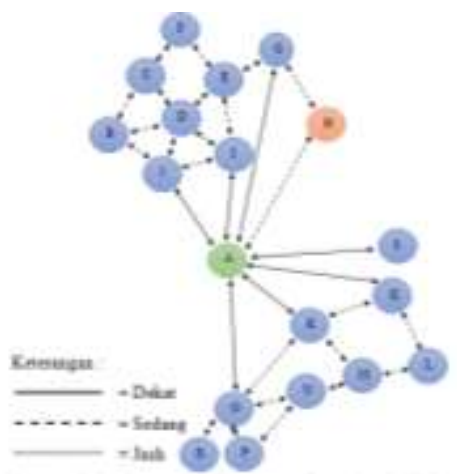

Gambar 24. Organisasi ruang Kantor Pemerintah Kabupaten Bandung

\section{Konsep Pola Penataan di Kantor Pemerintah Kabupaten Bandung}

\section{Konsep Pola Penataan Organisasi Terpusat}

Pola Penataan Organisasi kawasan Kantor Pemerintah Kabupaten Bandung yaitu Pola Penataan Organisasi Terpusat pada massa bangunan yang berada di tengah. Pada bagian tengah itu adalah gedung utama yang mengatur seluruh jajaran Badan Pemerintah di Kabupaten Bandung. Bangunan tersebut memberikan kesan monumental dan memberikan ruang terbuka guna memberikan sirkulasi dan ruang terbuka hijau.

Berikut Gambar Konsep Pola Penataan Organisasi Terpusat: 


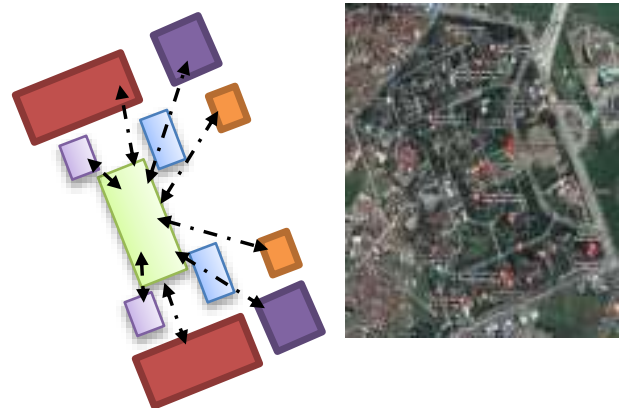

Gambar 25. Pola penataan organisasi ruang Kantor Pemerintah Kabupaten Bandung Keterangan :

$\boldsymbol{-} \cdot \boldsymbol{-} \cdot \boldsymbol{-}=$ Terpusat

\section{Konsep Pola Penataan Organisasi Grid}

Pola Penataan Organisasi Kawasan Kantor Pemerintah Kabupaten Bandung juga terdapat pola penataan organisai Grid yang membagi antar bangunan sehingga membuat penataan yang sangat rapih.

Berikut Gambar Konsep Pola Penataan Organisasi Grid:

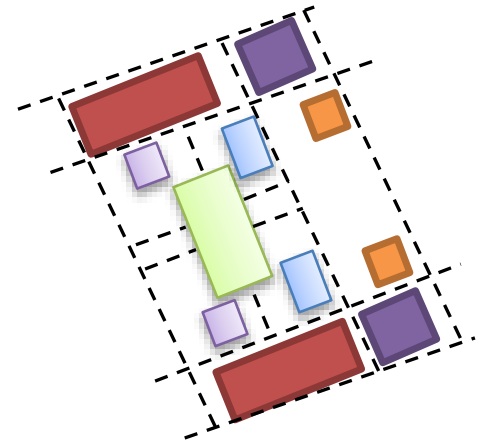

Gambar 26. Pola penataan organisasi ruang Kantor Pemerintah Kabupaten Bandung

Keterangan :

- - . = Sumbu Grid

\section{Penjabaran Mengenai Fasilitas Ruang} Kantor Pemerintah Kabupaten Bandung

1. Gedung kantor Bupati Bandung merupakan Tempat singga sana seorang pemimpin Kabupaten yang di kategorikan privasi karena tidak semua orang dapat masuk kedalam Gedung tersebut.

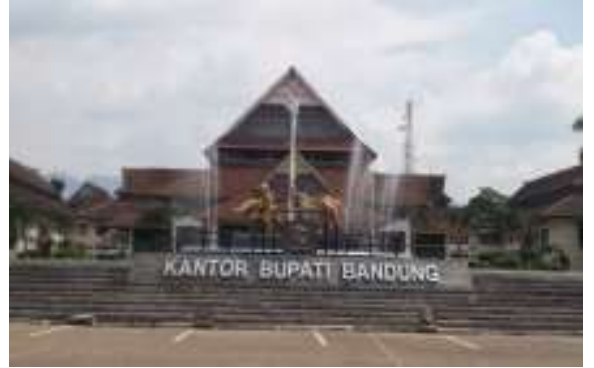

Gambar 27. Kantor Bupati Bandung

2. Gedung Dinas Pendidikan Merupakan tempat yang mengatur semua Pendidikan yang ada di Kabupaten Bandung dari sekolah dasar sampai sekolah menengah pertama dan sederajat.

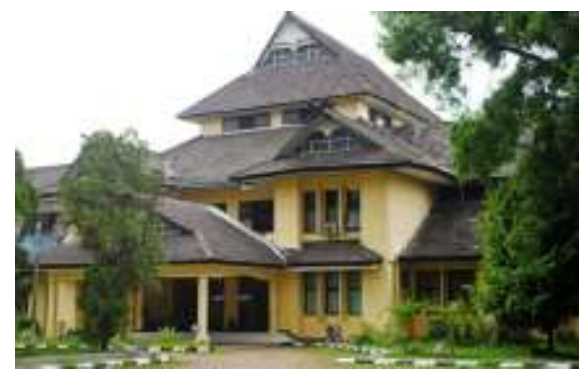

Gambar 28. Dinas Pendidikan

\section{Kantor Pemerintah Kabupaten Bekasi (Lokasi di Kabupaten Bekasi)}

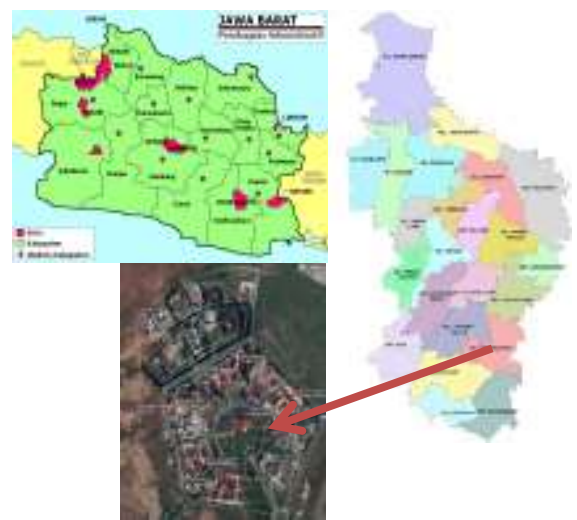

Gambar 29. Peta Lokasi Kantor Pemerintah Kabupaten Bekasi

Kantor Pemerintah Kabupaten Bekasi berlokasi di Sukamahi, Kecamatan Cikarang pusat, Bekasi, Jawa. Sebagai salah satu pusat pemerintahan di Jawa Barat, kantor pemerintah Kabupaten Bekasi ini mempunyai ciri tersendiri yang terpusatkan oleh lapangan terbuka hijau.

Pusat Pemerintahan yang berbentuk Pentagonal dengan luas $\pm 40 \mathrm{Ha}$ yang 
terbangun berbagai badan pemerintahan di dalamnya.

\section{Pembagian Zoning Kantor Pemerintah Kabupaten Bekasi}

Kantor Pemerintah Kabupaten Bekasi di bagi beberapa area yaitu Kantor Bupati, Kantor DPRD, Kantor Bawasda, Kantor, Bapeda, Kantor kejaksaan, Masjid raya, kantor Kepolisian Bekasi. Kantor Pemerintah Kabupaten Bekasi ini sebagai pusat pelayanan masyarakat.

Berikut Penataan Zoning Makro Kantor Pemerintah Kabupaten Bekasi:

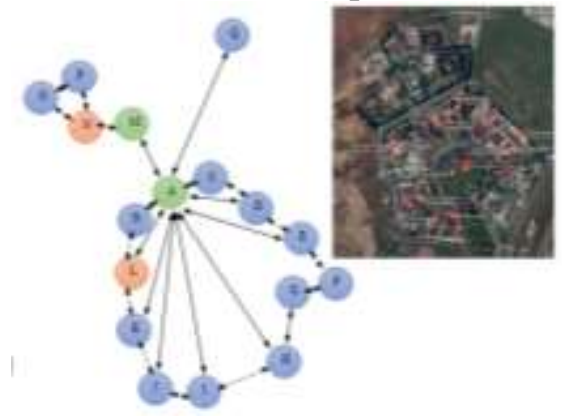

Gambar 30. Penataan zonasi Kantor Pemerintah Kabupaten Bekasi

Keterangan :

\begin{tabular}{|l}
$\square$ \\
$\square=$ Karakteristik Ruang Privat \\
$=$ =Karakteristik Ruang Semi \\
Publik \\
$=$ Karakteristik Ruang Publik
\end{tabular}

Fasilitas Kantor Pemerintah Kabupaten Bekasi

Kantor Pemerintah Kabupaten Bekasi memiliki beberapa fasilitas antara lain :

a. Gedung Utama, Badan Pengelolaan Keungan Daerah

b. Gedung Inspektorat

c. Gedung Bappeda

d. Gedung Serba Guna dan Pengadilan Negeri

e. Gedung Dinas Pariwisata, budaya, Pemuda dan Olahraga, Dinas Pedapatan daerah, Dinas Kependudukan dan catatan sipil

f. Kodim Bekasi 0509

g. Kejaksaan Negeri

h. Kantor Polisi

i. Kantor DPRD

j. Badan Pusat Statistik

k. Dinas Kementrian Lingkungan Hidup, Dinas PUPR, Dinas Pertanian, Dinas
Ketenagakerjaan, Dinas Kesehatan, Dinas Perindustrian dan Perdagangan.

1. Masjid, Pengadiln Negeri, Kementrian Agama.

\section{Konsep Organisasi Ruang Kantor Pemerintahan Kabupaten Bekasi}

Konsep organisasi ruang adalah pola penataan ruang yang terbentuk dari hubungan antar ruang. Organisasi ruang dapat diartikan sebagai pola penataan massa. Berikut gambaran konsep organisasi ruang pada Kantor Pemerintah Kabupaten Bekasi. Pertama organisasi ruang makro merupakan skema kedekatan setiap ruang yang saling berhubungan, organisasi ruang makro juga dapat disebut pola penataan massa sebelum terbentuknya sebuah denah, besaran ruang dapat digambarkan dengan kedekatan dan hubungan ruang agar memudahkan membuat denah dan juga kita dapat melihat perbedaan area atau zoning ruang pada Kantor Pemerintah Kabupaten Bekasi.

Berikut merupakan organisasi kedekatan ruang makro :

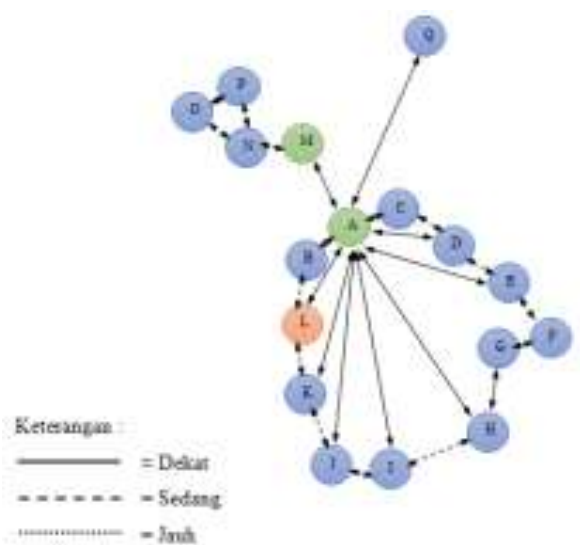

Gambar 31. Organisasi ruang Kantor Pemerintahan Kabuoaten Bekasi

\section{Konsep Pola Penataan Organisasi di Kantor Pemerintahan Kabupaten Bekasi}

\section{Pola Penataan Organisasi Ring}

Pola Penataan Organisasi kawasan Kantor Pemerintah Kabupaten Bekasi menerapkan pola organisasi Ring karena semua bangunan melingkar mengelilingi Ring atau lingkaran yaitu lapangan dan semua bangunan berorientasi menghadap lapangan tersebut. 
Berikut Gambar Konsep Penataan Bentuk Massa Ring:

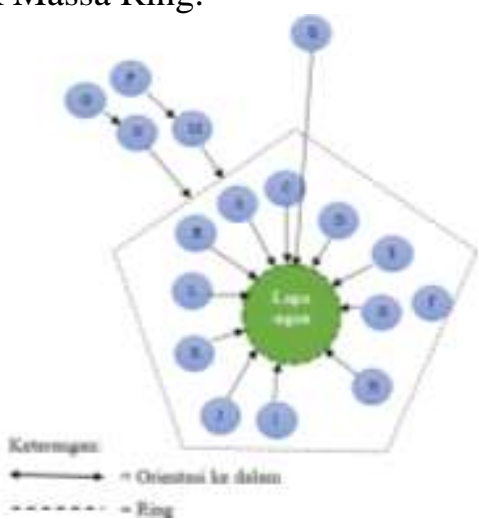

Gambar 32. Konsep Penataan Bentuk Massa Ring

\section{Pola Penataan Organisasi Radial}

Pola Penataan Organisasi kawasan Kantor Pemerintah Kabupaten Bekasi juga menerapkan pola organisasi Radial Masingmasing sumbu akses jalan mengarah ke titik tengah atau lapangan. Sumbu-sumbu tersebut berbentuk jari-jari yang memusatkan ke daerah lapangan.

\section{Berikut Gambar Konsep Penataan} Bentuk Massa Radial:

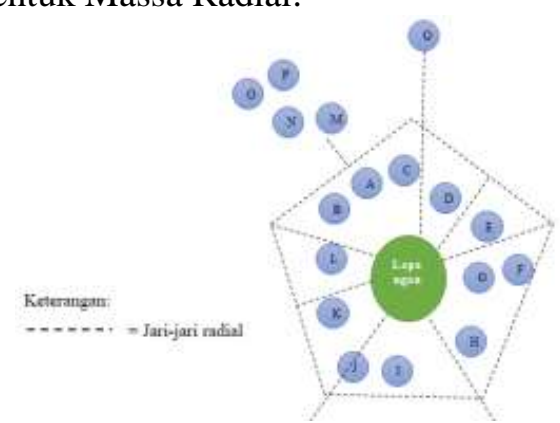

Gambar 33. Konsep Penataan Bentuk Massa Radial

\section{Penjalbaran Mengenai Fasilitas Kantor Pemerintah Kabupaten Bekasi}

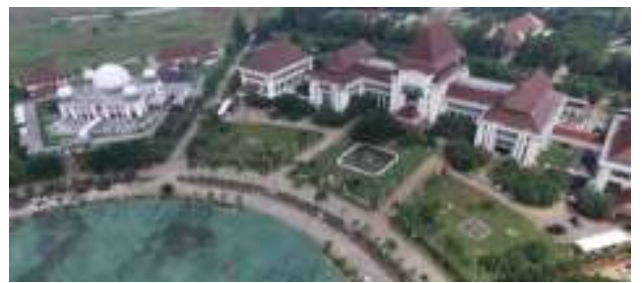

Gambar 34. Tampak atas Pemerintah Kabupaten Bekasi

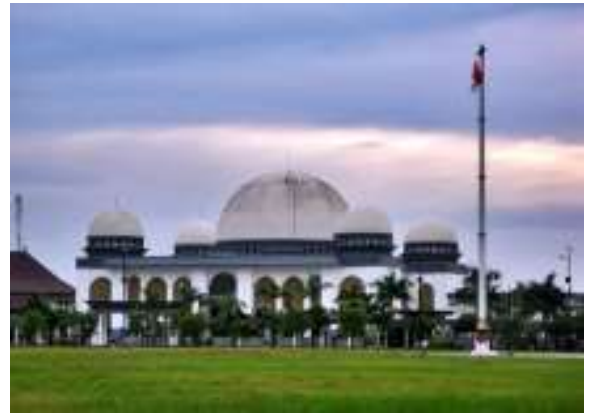

Gambar 35. Tampak Masjid Agung Nurul Hikma

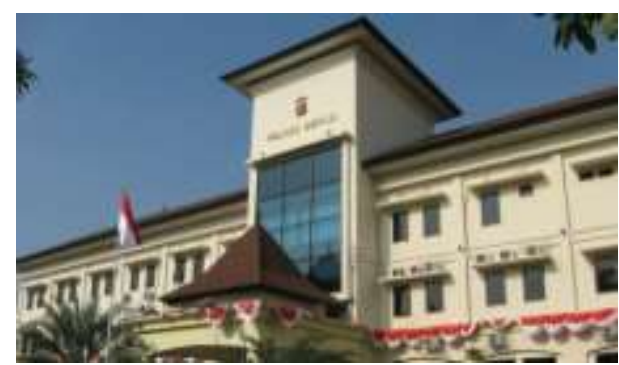

Gambar 36. Kantor Kepolisian

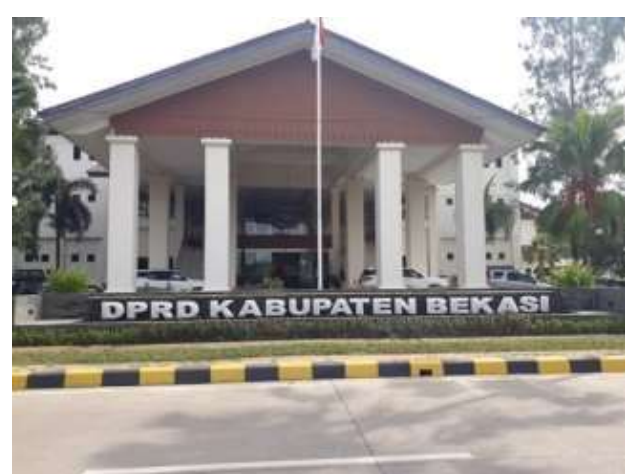

Gambar 37. Gedung DPRD

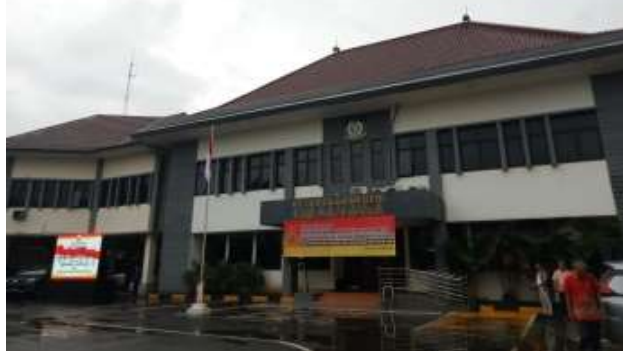

Gambar 38. Kantor Kejaksaan Negeri 


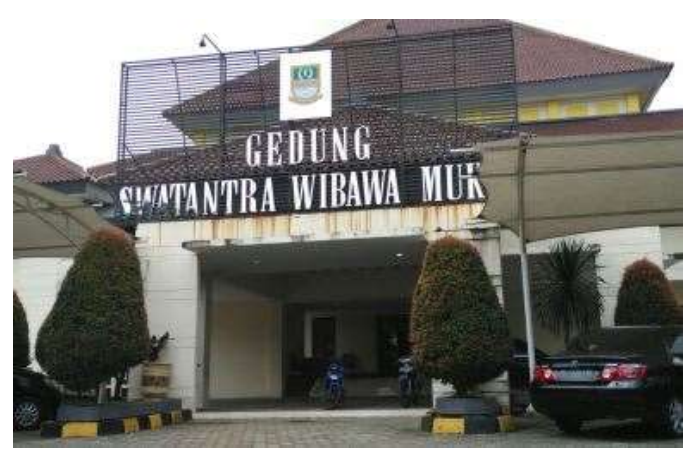

Gambar 39. Gedung serba guna

\section{Kantor Pemerintah Kabupaten Grobogan}

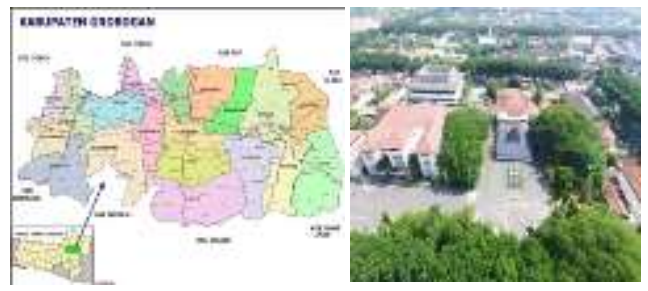

Gambar 40. Peta lokasi Kantor Pemerintah Kabupaten Grobogan

Kantor Pemerintah Kabupaten Grobogan merupakan kawasan pusat pemerintahan wilayah kabupaten grobogan yang terletak di Jl. Gatot Subroto No.6, Brambangan, Purwodadi, Kec. Purwodadi, Kabupaten Grobogan, Jawa Tengah.

\section{Visi dan Misi Kantor Pemerintah Kabupaten Grobogan}

Visi

"Terwujudnya Masyarakat Kabupaten Grobogan yang Sejahtera Secara Utuh dan Menyeluruh"

\section{Misi}

1. Membangun fasilitas infrastruktur.

2. Meningkatkan produktivitas pertanian

3. Pengembangan ekonomi kerakyatan bidang industry, UMKM, koperasi, pariwisata dan perdagangan

4. Peningkatan kualitas pelayanan Kesehatan, pendidikan, keolahragaan pemuda, KB dan pelayanan sosial dasar lainnya

5. Mewujudkan suasana investasi yang kondusif dan mewadahi penyerapan tenaga kerja

6. Meningkatkan kualitas aparat, tata kelola pemerintah yang akuntabel dan kualitas pelayanan publik
7. Melestarian sumberdaya alam, lingkungan hidup.

8. Meningkatkan Penghayatan keagamaan dan pelestarian kebudayaan masyarakat.

9. Pemerataan pendapatan, pengembangan antar wilayah, kesetaraan gender, dan penanggulangan kemiskinan

\section{Konsep inti Kantor Pemerintah} Kabupaten Grobogan Sebagai berikut :

1. Gedung Utama ditempatkan di lantai 1 karena mengutamakan privasi Bupati, dan bangunan berbentuk joglo agar mempertahan kan budaya jawa yang masih kental di kabupaten grobogan.

2. Gedung Sekertaris daerah di konsep seperti bangunan monumental tetapi mengarah ke modern.

3. Penataan Pola bangunan di lakukan terpisah bertujuan untuk mengorientasikan bangunan terhadap alun-alun yang sangat luas dan hijau.

4. Jalur di buat melingkar mengelilingi alun-alun bertujuan agar tida terjadi kemacetan.

\section{Pembagian Zoning Kantor Pemerintah Kabupaten Grobogan}

Kantor Pemerintah Kabupaten Grobogan di letakan secara terpisah karena agar saat ada tamu tidak terlalu ramai dan mengurangi tingkat kebisingan pengguna. Dan bertujuan memperluas fasilitas parkir di masingmasing Gedung.

Penataan Zoning Makro Kantor Pemerintah Kabupaten Grobogan

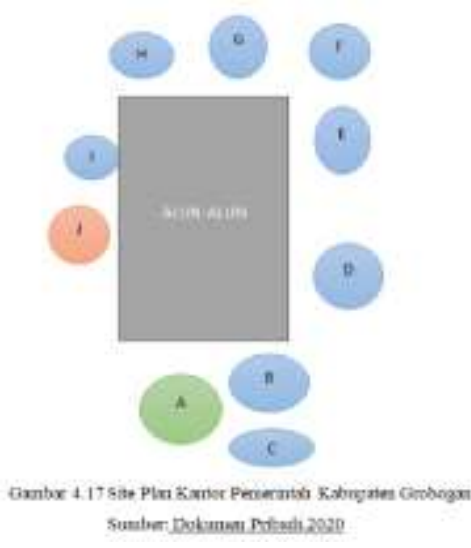


Gambar 41. Zoning Makro Kantor

Pemerintah Kabupaten Grobogan

Keterangan :

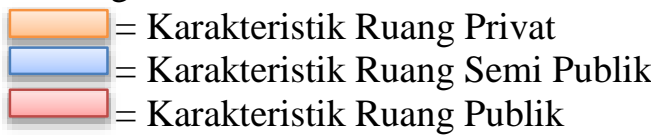

\section{Fasilitas Kantor Pemerintah Kabupaten} Grobogan

Kantor Pemerintah Kabupaten Grobogan memiliki beberapa fasilitas antara lain:

a. Pendopo, Kantor Bupati

b. Kantor Sekda

c. Kantor Badan Pengelolaan Pendapatan Daerah dan Badan Perencanaan

Pembangunan Daerah

d. Perumahan Perhutani

e. Kantor Kejaksaan Negeri

f. Kantor Polsek

g. Kantor DPRD

h. Kantor Dinas Pemuda Olah Raga

Kebudayaan dan Pariwisata

i. Kantor Urusan Agama

j. Masjid

\section{Konsep Organisasi Ruang Kantor Pemerintah Kabupaten Grobogan}

Berikut gambaran konsep organisasi ruang pada Kantor Pemerintah Kabupaten Grobogan. Pertama organisasi ruang makro merupakan skema kedekatan setiap ruang yang saling berhubungan, organisasi ruang makro juga dapat disebut pola penataan massa sebelum terbentuknya sebuah denah, besaran ruang dapat digambarkan dengan kedekatan dan hubungan ruang agar memudahkan membuat denah dan juga kita dapat melihat perbedaan area atau zoning ruang pada Kantor Pemerintah Kabupaten Grobogan.

Berikut merupakan organisasi kedekatan ruang makro kawasan Kantor Pemerintah Kabupaten Grobogan.

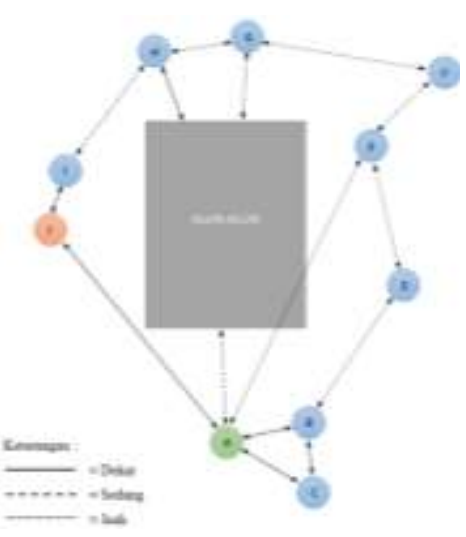

Gambar 42. Organisasi ruang Kantor Pemerintah Kabupaten Grobogan

Konsep Pola Penataan Organisasi di
kantor Pemerintah Kabupaten Grobogan

Pola Penataan Organisasi Grid

Pola Penataan Organisasi massa di kawasan Kantor Pemerintah Kabupaten Grobogan pola penataan organisasi grid yang terbagi oleh sumbu dan membagi antar massa bangunan sehingga membuat penataan yang sangat rapih.

Berikut Gambar Konsep Pola Penataan Bentuk Massa Organisasi Grid:

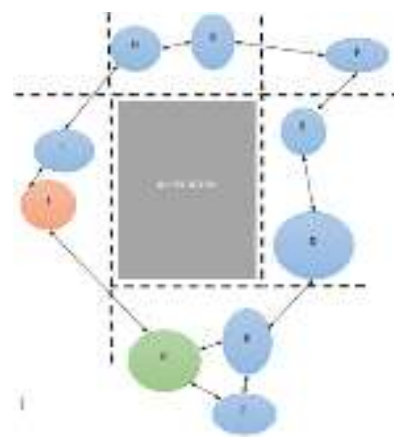

Gambar 43. Konsep Pola Penataan Bentuk Massa Organisasi Grid

Keterangan:

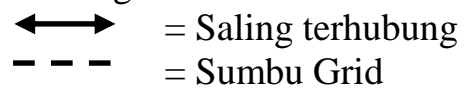

\section{Pola Penataan Organisasi Terpusat}

Pola Penataan Organisasi massa di kawasan Kantor Pemerintah Kabupaten Grobogan pola penataan organisasi terpusat yang terpusat pada orientasi menghadap ke alun-alun Kabupaten Grobogan dan berorintasi terhadap sumbu ke dalam.

Berikut Gambar Konsep Pola Penataan Bentuk Massa Organisasi terpusat: 


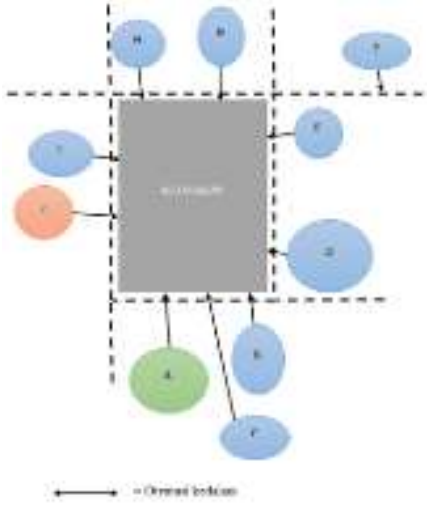

Gambar 44. Pola penataan organisasi terpusat Kantor Pemerintahaan Kabupatem Grobogan

Keterangan:

$\longleftrightarrow \quad=$ Saling terhubung

- - = Sumbu Grid

\section{Penjabaran Mengenai Fasilitas Kantor Pemerintah Kabupaten Grobogan}

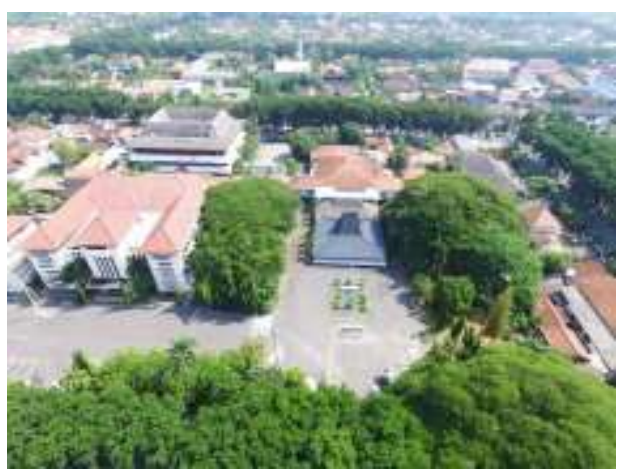

Gambar 45.

Penataan bangunan yang terjadi spase yang sangat luas dimanfaatkan sebagai lahan parkir tamu yang berkunjung.

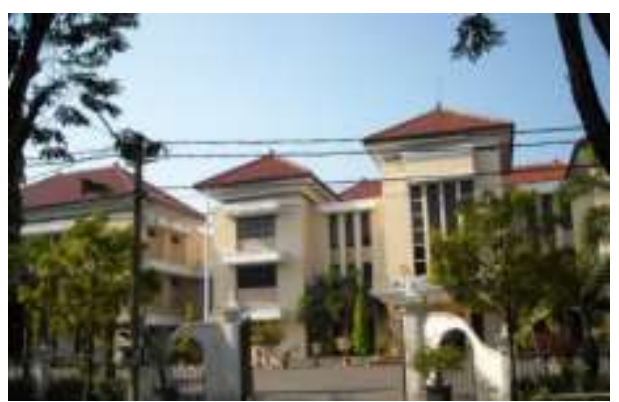

Gambar 46. Gedung Sekretaris Daerah

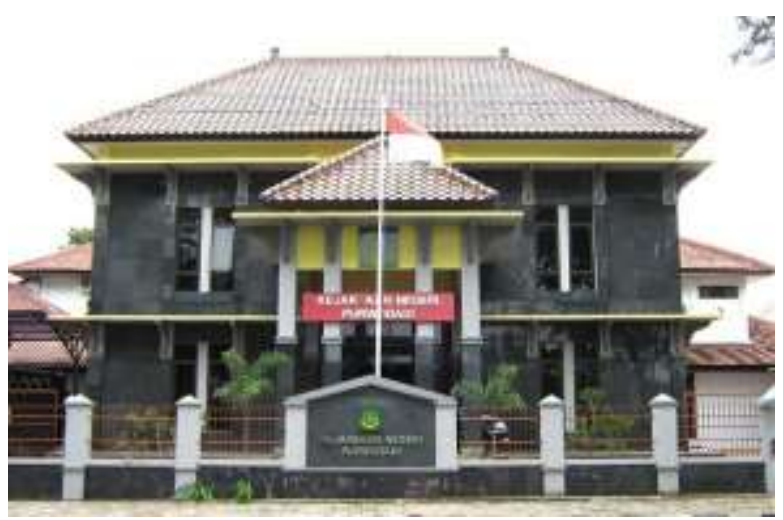

Gambar 47. Gedung Kejaksaan Negeri

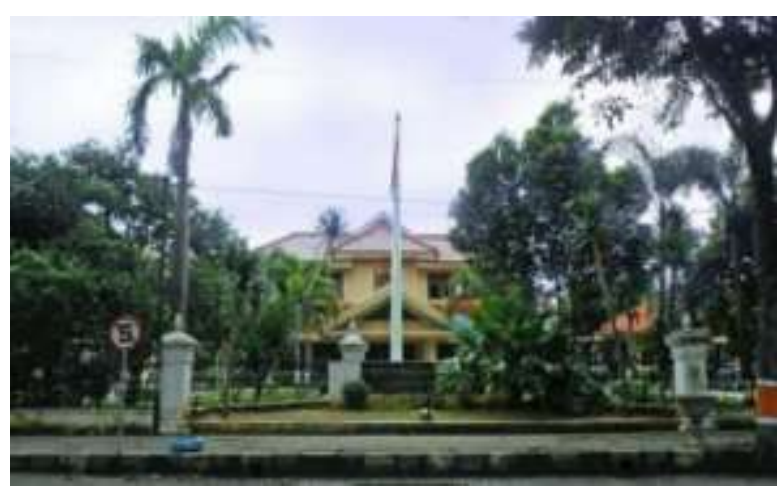

Gambar 48. Gedung DPRD

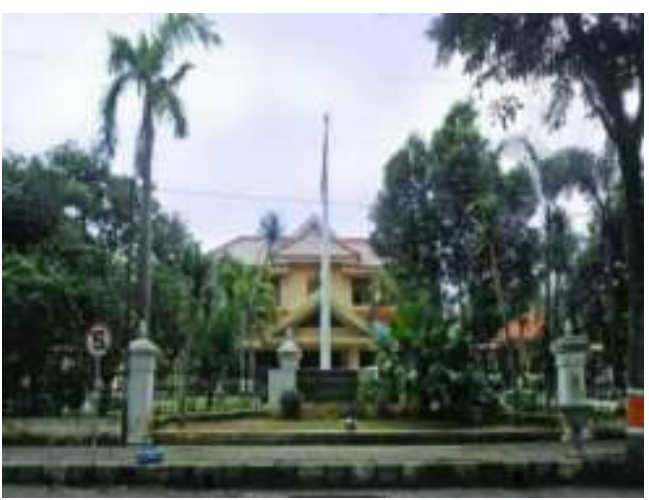

Gambar 49. Masjid

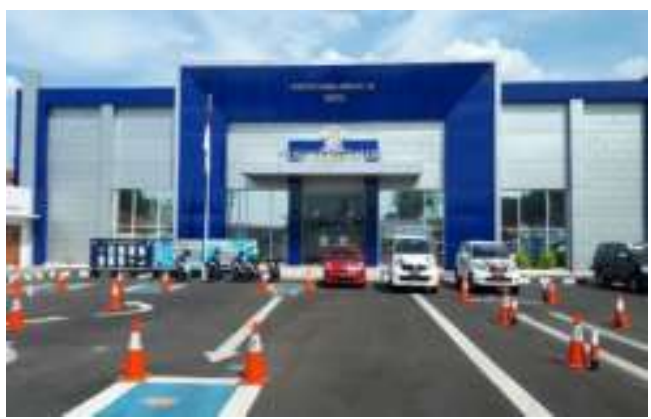

Gambar 50. Polsek 
4.2 Analisis Terhadap Permasalahan data dan fakta

4.2.1 Kantor Kabupaten/Kota meneliti 3 kantor yaitu:

Tabel 1. Analisa terhadap permasalahan berdasarkan data dan fakta

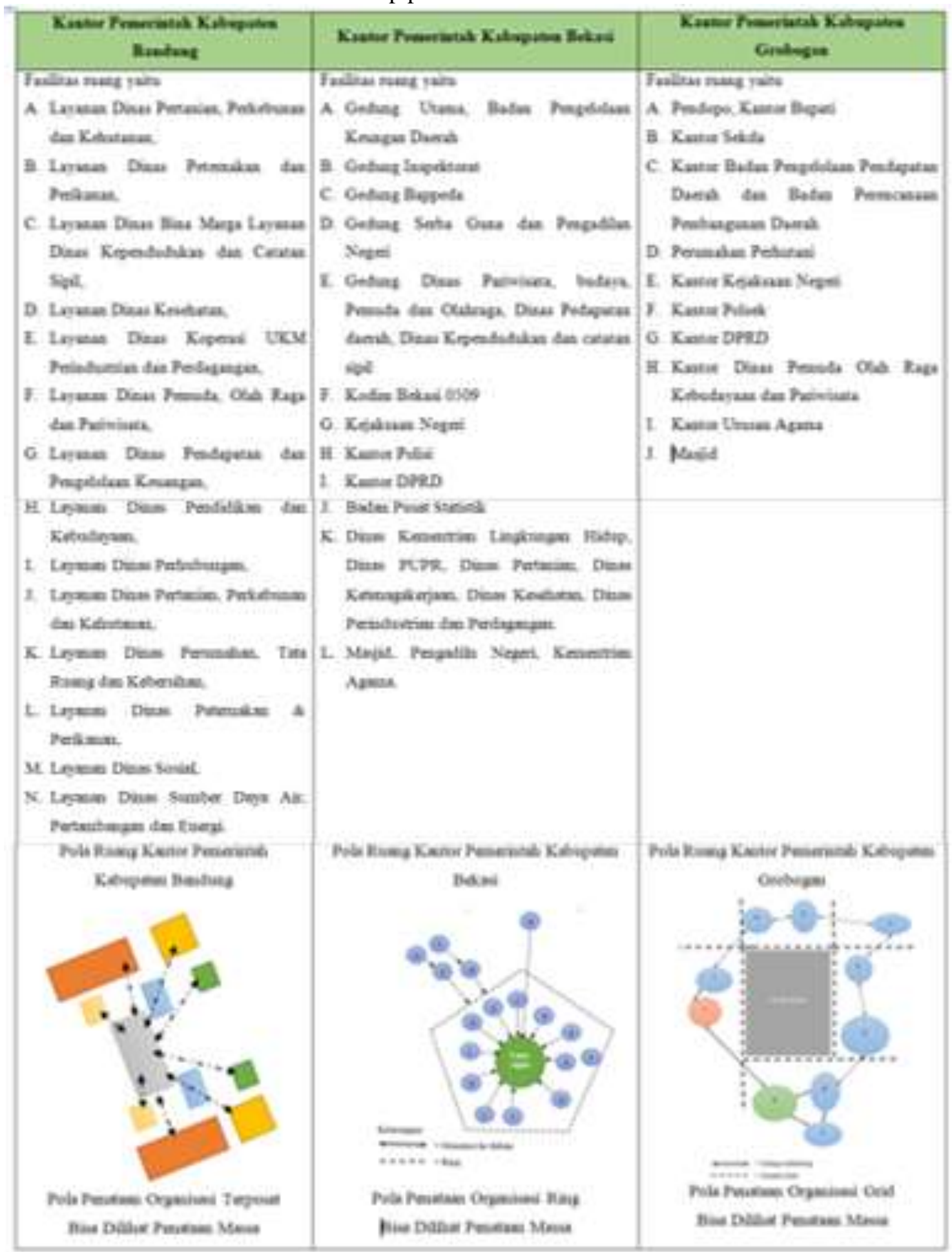




\begin{tabular}{|c|c|c|}
\hline 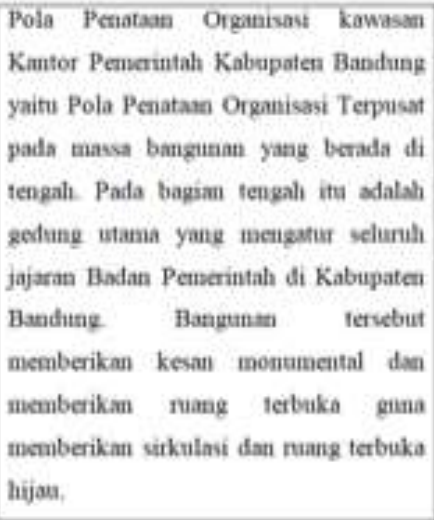 & 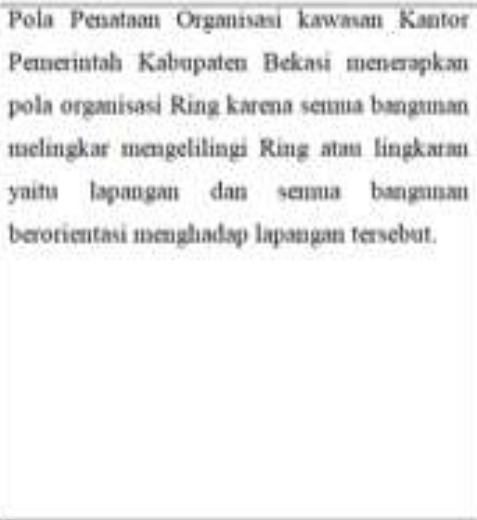 & $\begin{array}{l}\text { Pola Petataan Organisast massa di } \\
\text { kawasan Kantor Pemerintah Kabupaten } \\
\text { Grobogan pola penataan organisasi grid } \\
\text { yaug terbagi olch sambu dan unembagi } \\
\text { antar massa bangunan sehingsa membuat } \\
\text { penataan yang sanpat rapih. }\end{array}$ \\
\hline 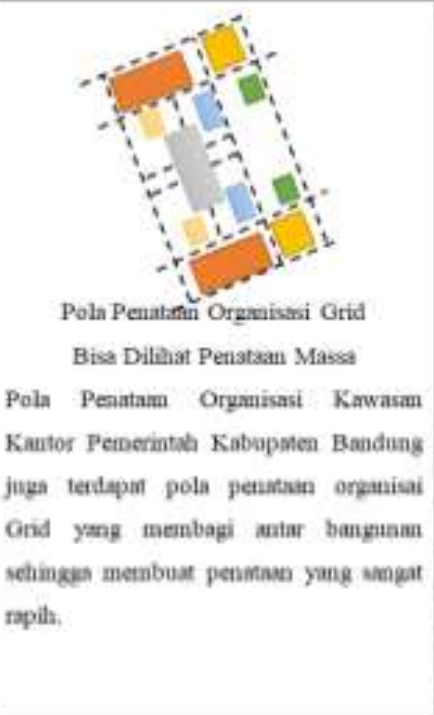 & 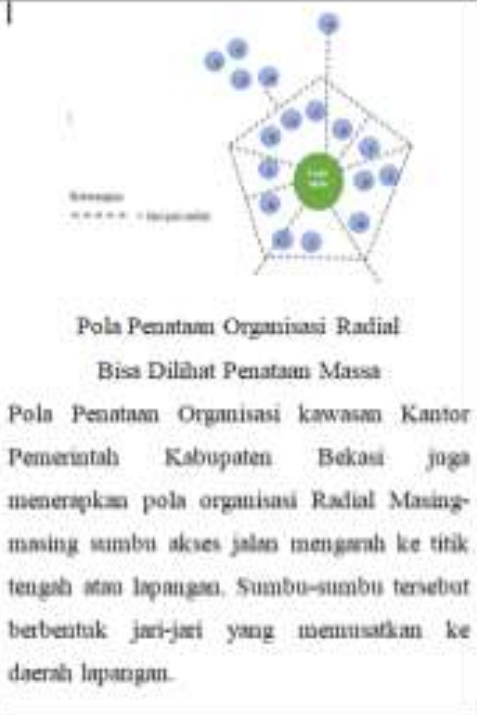 & 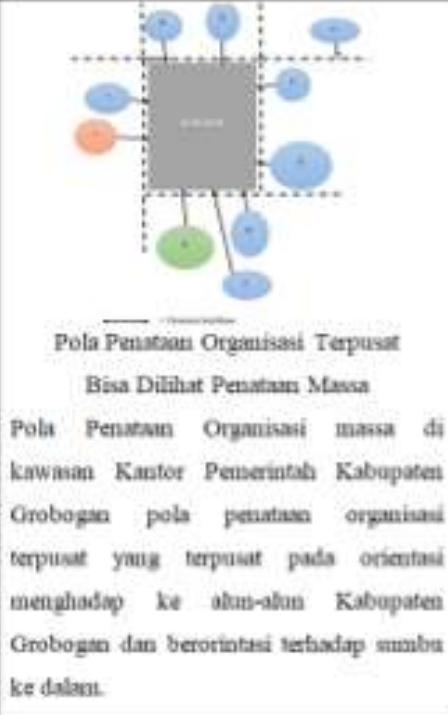 \\
\hline
\end{tabular}

\section{KESIMPULAN}

Kesimpulan dari hasil penelitian dan pembahasan mengenai studi penelitian yaitu :

Studi Penelitian Kantor Pemerintah Kabupaten/Kota ini yaitu: Kabupaten Bandung, Kabupaten Bekasi, Kabupaten Grobogan.

\section{Kantor Pemerintah Kabupaten Bandung}

Menerapkan Pola Penataan Organisasi Terpusat Bisa Dilihat Penataan Massa.

Pola Penataan Organisasi kawasan Kantor Pemerintah Kabupaten Bandung yaitu Pola Penataan Organisasi Terpusat pada massa bangunan yang berada di tengah. Pada bagian tengah itu adalah Gedung utama yang mengatur seluruh jajaran Badan Pemerintah di Kabupaten Bandung. Bangunan tersebut memberikan kesan monumental dan memberikan ruang terbuka guna memberikan sirkulasi dan ruang terbuka hijau.
Menerapkan Pola Penataan Organisasi Grid Bisa Dilihat Penataan Massa.

Pola Penataan Organisasi Kawasan Kantor Pemerintah Kabupaten Bandung juga terdapat pola penataan organisai Grid yang membagi antar bangunan sehingga membuat penataan yang sangat rapih.

\section{Kantor Pemerintah Kabupaten Bekasi}

Menerapkan Pola Penataan Organisasi Ring Bisa Dilihat Penataan Massa.

Pola Penataan Organisasi kawasan Kantor Pemerintah Kabupaten Bekasi menerapkan pola organisasi Ring karena semua bangunan melingkar mengelilingi Ring atau lingkaran yaitu lapangan dan semua bangunan berorientasi menghadap lapangan tersebut.

Dan juga menerapkan Pola Penataan Organisasi Radial bisa dilihat Penataan Massa. 
Pola Penataan Organisasi kawasan Kantor Pemerintah Kabupaten Bekasi juga menerapkan pola organisasi Radial Masing-masing sumbu akses jalan mengarah ke titik tengah atau lapangan. Sumbu-sumbu tersebut berbentuk jarijari yang memusatkan ke daerah lapangan.

\section{Kantor Pemerintah Kabupaten Grobogan}

Menerapkan Pola Penataan Organisasi Grid Bisa dilihat Penataan Massa

Pola Penataan Organisasi massa di kawasan Kantor Pemerintah Kabupaten Grobogan pola penataan organisasi grid yang terbagi oleh sumbu dan membagi antar massa bangunan sehingga membuat penataan yang sangat rapih.

Dan juga menerapkan Pola Penataan Organisasi Terpusat bisa dilihat Penataan Massa.

Pola Penataan Organisasi massa di kawasan Kantor Pemerintah Kabupaten Grobogan pola penataan organisasi terpusat yang terpusat pada orientasi menghadap ke alun-alun Kabupaten Grobogan dan berorintasi terhadap sumbu ke dalam.

\section{DAFTAR PUSTAKA}

Ching, Francis D.K. Arsitektur Bentuk, Ruang, dan Tananan. Jakarta. Penerbit Erlangga

http://www.bandungkab.go.id/

http://alamat-kantorpemerintah.com/kabupaten/alamat/133/K abupaten-Bandung

http://bekasikab.go.id/

http://kota-deltamas.com/tentang-kami/centralof-bekasi-regency/

https://grobogan.go.id 